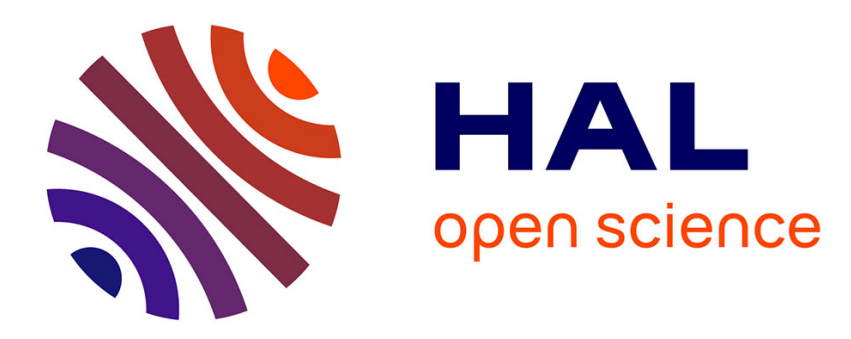

\title{
Iron metabolism and related genetic diseases: a cleared land, keeping mysteries
}

\author{
Pierre Brissot, Olivier Loréal
}

\section{To cite this version:}

Pierre Brissot, Olivier Loréal. Iron metabolism and related genetic diseases: a cleared land, keeping mysteries. Journal of Hepatology, 2016, 64 (2), pp.505-515. 10.1016/j.jhep.2015.11.009 . hal01231421

HAL Id: hal-01231421

https://hal-univ-rennes1.archives-ouvertes.fr/hal-01231421

Submitted on 7 Jan 2016

HAL is a multi-disciplinary open access archive for the deposit and dissemination of scientific research documents, whether they are published or not. The documents may come from teaching and research institutions in France or abroad, or from public or private research centers.
L'archive ouverte pluridisciplinaire HAL, est destinée au dépôt et à la diffusion de documents scientifiques de niveau recherche, publiés ou non, émanant des établissements d'enseignement et de recherche français ou étrangers, des laboratoires publics ou privés. 
TITLE PAGE

TITLE : IRON METABOLISM AND RELATED GENETIC DISEASES : A CLEARED LAND, KEEPING MYSTERIES

NAMES OF THE AUTHORS : Pierre BRISSOT and Olivier LOREAL

AFFILIATIONS : Inserm-UMR 991, National Center of Reference for Rare Iron Overload Diseases

University Hospital Pontchaillou, Faculty of Medicine, Rennes (France)

CORRESPONDING AUTHORS :

- Pierre Brissot - Hepatology - Faculty of Medicine, 2 Avenue Pr. Léon Bernard - 35043 - Rennes (France) ; tel : (33)0223235469; e-mail : pierre.brissot@univ-rennes1.fr

- Olivier Loréal : Inserm U-991-Pontchaillou Hospital, 2 Rue Henri Le Guilloux- 35033-Rennes (France) ; tel : (33)0223233865 ; e-mail : olivier.loreal@inserm.fr

ELECTRONIC WORD COUNT (abstract + text+ key points) :

WORDS : 4565

. CHARACTERS : 31138 (characters (spaces included)

NUMBER OF FIGURES : 6

NUMBER OF TABLES : 0

KEYWORDS : Iron, transferrin, ferritin, hepcidin, ceruloplasmin, ferroportin, erythroferrone, nontransferrin bound iron, hemojuvelin, transferrin receptor, haemochromatosis, liver.

\section{CONFLICT OF INTEREST : None}

FINANCIAL SUPPORT : Eurolron1 (European Community Grant ; IronReg (French National Research Agency) ; Afemers Association.

AUTHORS' CONTRIBUTIONS: PB and OL contributed equally to the design and the writing of the manuscript. 
ABSTRACT

Body iron has a very close relationship with the liver. Physiologically, the liver synthetizes transferrin, in charge of blood iron transport, ceruloplasmin, acting through its ferroxidase activity, and hepcidin, the master regulator of systemic iron. It also stores iron inside ferritin and serves as an iron reservoir, both protecting the cell from free iron toxicity and ensuring iron delivery to the body whenever needed. The liver is first in line for receiving iron from the gut and the spleen, and is, therefore, highly exposed to iron overload when plasma iron is in excess, especially through its high affinity for plasma non-transferrin bound iron. The liver is strongly involved when iron excess is related either to hepcidin deficiency, as in HFE, hemojuvelin, hepcidin, and transferrin receptor2 related haemochromatosis, or to hepcidin resistance, as in type B ferroportin disease. It is less involved in the usual (type A) form of ferroportin disease which targets primarily the macrophagic system. Hereditary aceruloplasminemia raises important pathophysiological issues in light of its peculiar organ iron distribution. 
Iron is the best and the worst thing for the human body. Iron being deeply involved in a number of critical metabolic processes, lack of this metal impairs body functioning, especially in the haematological domain. Conversely, excessive body iron is the source of multiple cellular and visceral damage. These two "mirror" hazards explain why iron homeostasis is a crucial need. For this physiological purpose, a myriad of metabolic actors, particularly proteins, are involved in iron metabolism. Structural and/or functional disturbances of these actors, of acquired or genetic origin, may cause severe diseases, related either to iron deficiency or to iron overload. The liver plays a key role in iron homeostasis, not only as the source of major protein actors, among which transferrin, ceruloplasmin, and mostly hepcidin, but also as the main iron storage organ and a preferential target of iron overload toxicity(1). Although the iron domain has benefited from major advances, a number of issues remain to be solved.

\section{IRON METABOLISM : "THE TEN IRON LAWS »}

Iron homeostasis is governed by inescapable laws. A failure to follow these rules, especially due to inborn errors, favors the development of iron metabolism diseases(2-4).

\subsection{IRON IS NOT DISPENSABLE}

Total body iron load normally approximates three to four grams. Two-thirds of this iron quantity are contained in red blood cells, within the hemoglobin molecules. Iron (Fe) is part of the porphyrin ring of the heme molecule, and has a major ability for linking oxygen(5). Erythrocytic iron circulates in the plasma and delivers oxygen to all cells, while being itself delivered to the bone marrow in order to contribute to the daily production of approximately 200 billions of new red blood cells(6). Therefore, iron plays a major role in the respiratory process, and without iron, the human body could not breath. This is as more true as iron is also involved, at the cellular and molecular levels, in the respiratory chain which serves to the production of energy through ATP production. The muscle, through iron incorporation inside myoglobin, has a special place in this energy process. Iron is also involved in multiple enzyme activities catalysing metabolic processes such as xenobiotics biotransformation, lipid metabolism, collagen production, or DNA synthesis.

\subsection{IRON IS NOT PRODUCED BY THE BODY WHICH IS THEREFORE EXPOSED TO IRON DEFICIENCY}

The only iron source is alimentary. Normal diet provides 10-20 mg per day, of which one tenth (1$2 \mathrm{mg}$ ) only is absorbed(4). Within the digestive tract, iron exists under two forms : heme iron (meat, fish) and non heme iron (cocoa, cereals with the highest content in lentils). As to spinach, its iron content is far from initially (erroneously) reported (the "Popeyes'syndrome »...), but remains significant since it is close to that of meat. Iron is absorbed at the duodenal level and this absorption process is approximately five times more efficient for heme iron than for non heme iron.

Chronic lack of dietary iron unavoidably leads to iron deficiency. Two main situations are concerned. If digestive absorption is normal, deficient alimentary input is either " absolute " (malnutrition) or " relative " (increased physiological iron needs, especially during infancy, adolescence, pregnancy, and lactation). The second mechanism is defective iron absorption. It may be due to alimentary co- 
factors which are capable to decrease iron absorption (for example, tannins contained especially in tea and at a lesser degree in coffee, or phytates contained in seeds, legumes and nuts) or to increase it (vitamin C(7)). These co-factors interfere preferentially with non-heme iron absorption. Beside the role of co-factors, defective iron absorption may be related to damage of the absorption process itself (corresponding to malabsorption, such as occurring in coeliac disease(8)).

\subsection{THE FATE OF IRON AFTER INTESTINAL ABSORPTION IS MAINLY THE ERYTHROCYTE (FIg.1)}

Once iron has crossed the digestive barrier, at the duodenal level, it reaches the blood, is linked to its carrier protein transferrin, and is predominantly (up to $80 \%$ ) directed toward the bone marrow. It enters the erythroblasts via transferrin receptor 1 and undergoes the classical transferrin-iron cycle. The remnant part (20\%) goes into the various extramedullary cells in order to participate to many metabolic processes (respiration, xenobiotic biotransformation, DNA synthesis).

\subsection{IRON CANNOT CIRCULATE WITHIN THE BODY, OR BE STORED, IN A FREE FORM}

Being a metal, iron is neither soluble in the plasma nor in the cytosol. Therefore, it must be linked to other molecules in order to avoid toxicity linked to the ability of iron to generate Reactive Oxygen Species (ROS).

1.4.1. In the blood, plasma iron is physiologically taken up by transferrin, with a normal linkage ratio between the theoretical capacity of iron binding to transferrin ( 2 iron atoms per transferrin molecule) and plasma iron concentration of less than 45\% (transferrin saturation- TS). Whenever TS increases over 45\%, new circulating iron species can appear, named non-transferrin bound iron (NTBI)(9). NTBI has a very special kinetics in so far as, in contrast with transferrin iron, it targets preferentially -and with very high affinity- the parenchymal cells, especially the hepatocytes $(10,11)$. NTBI uptake by the hepatocytes involves mostly solute carrier SLC39A14 (ZIP14)(12, 13). This NTBI is not a "free" iron but is likely linked to low molecular weight ligands (citrate, acetate) or to carboxylic groups of albumin(14). When TS exceeds 75\%, a peculiar NTBI form, called labile plasma iron (LPI) or reactive plasma iron, defined by its capacity for producing ROS, may appear. It corresponds to a potentially toxic form of circulating iron(15-19). Iron can also be transported by indirect systems, such as haptoglobin binding haemoglobin, and hemopexin binding free heme (coming from intravascular hemolysis).

1.4.2. In the cytosol, iron is essentially stored inside the ferritin molecules. Each ferritin molecule may store up to 4500 iron atoms. Ferritin acts as an iron "sponge ", storing the metal in case of excessive influx for avoiding cellular iron toxicity, and releasing iron in case of body iron deficiency to avoid anemia.

\subsection{THE IRON REDOX STATE MAINTENANCE IS FUNCTIONALLY CRITICAL}

The iron property to exist under two redox forms, the oxidized one -ferric iron $\left(\mathrm{Fe}^{3+}\right)$ - and the reduced one -ferrous iron ( $\mathrm{Fe}^{2+}$ )- is of major functional importance at four main levels (Fig.2).

1.5.1. Transmembrane iron transport. Whatever the cell (enterocyte, hepatocyte, macrophage), iron crosses its plasma and intracellular membranes under the ferrous form $\left(\mathrm{Fe}^{2+}\right)$. This explains the importance of iron reducing proteins. The main ferro-reductases are DCYTB (duodenal cytochrome B)(20), which reduces alimentary non heme iron to permit its luminal entry into the enterocyte 
through DMT1 (Divalent Metal Transporter 1)(20), and STEAP3 (Six-Transmembrane Epithelial Antigen of the Prostate 3)(21). STEAP3 reduces intra-endosomal iron thus permitting, through DMT1 expressed on the endosomal membrane, its cytosolic delivery for cellular metabolism or storage.

1.5.2. Plasma iron delivery and transport. Iron is carried by transferrin under the ferric form. Since it is released from the cells in the ferrous form, ferroxidases are necessary for enabling ferrous iron to be taken up by transferrin. This role is ensured by multicopper oxidase proteins : ceruloplasmin(22) for macrophages, and hephastin(23) for enterocytes.

1.5.3. Cellular iron storage. Iron is stored within ferritin(24) under its ferric form $\left(\mathrm{Fe}^{3+}\right)$ and needs reduction to be released. Ferritin is formed by 24 subunits of two forms ( $L$ and $H$, encoded by two different genes). The $\mathrm{H}$ form possesses a ferroxidase activity permitting iron internalization. Vitamin $C$, when acting as a reducing agent, can favor iron delivery from ferritin(25).

1.5.4. Iron toxicity(26). The transition from ferric to ferrous iron, through the Fenton reaction, generates the production of ROS which can damage cellular membranes and nuclei. This mechanism is recognized as the main cause of cellular and organ damage in iron overload.

1.6. THE IRON BODY HAS LIMITED EXCRETORY CAPACITIES AND IS THEREFORE EXPOSED TO IRON OVERLOAD

The main exit pathways of iron are represented by intestinal exfoliation, skin desquamation, sweat, urine, bile and, in women, menstruations. Although biliary iron excretion may undergo some adaptation to body iron load(27), it is globally admitted that the ability of the human body to regulate its iron stores through iron excretion is very limited.

As a consequence of its poor excretory capacity, the human body is prone to iron overload, whatever the iron source. These sources can be either enteral as in hepcidin-deficient related haemochromatosis(28) or dyserythropoiesis(29), or parenteral as caused by uncontrolled iron injections (for iron deficiency anemia(30)) or repeated transfusions(31) (for hemoglobinopathies or myelodysplastic syndromes).

\subsection{IRON RECYCLING IS A CRUCIALPERMANENT PROCESS}

Since the daily quantity of iron entering and leaving the body is minimal (1-2mg), as compared to the daily body iron needs (of the order of $20 \mathrm{mg}$ ), an intense and constant recycling process, involving a bone marrow-spleen-bone marrow " virtuous » circle occurs to ensure plasma iron sufficiency. It is estimated than one billion iron atoms are required daily for producing the hemoglobin of new red blood cells(32). Therefore, the "ecological attitude", and therefore energy preservation, are hallmarks of iron metabolism.

\subsection{SYSTEMIC IRON HOMEOSTASIS NECESSITATES A FINELY TUNED REGULATION: THE HEPCIDIN- FERROPORTIN DUO (Fig.3)}

The master regulator of iron metabolism is the protein hepcidin(33-36) which acts in close connection with ferroportin. Hepcidin is mainly produced by the liver (hepatocytes). This hormone is a small peptide whose mature and active part consist of 25 aminoacids. Body iron load is a main regulator of hepcidin synthesis(37). Physiologically, iron homeostasis functions as follows: when plasma or hepatocyte iron concentration increases, there is an activation of signalling pathways, 
including the ERK (extracellular signal regulating kinase) MAPK (mitogen activated protein kinase) pathway, and the BMP (bone morphogenetic proteins)/ SMAD (son of mothers aaginst decapentaplegic homologues) pathway, respectively. There are likely crosstalks between these two pathways(38-40). As to HFE, which may be primarily concerned by the ERK-MAPK pathway, it has been reported to interact with the BMP type 1 receptor ALK3 to regulate hepcidin expression(41). It is likely that these two types of signals (plasma iron and hepatocytic iron) correspond to differential chronological reactivity. Thus, the regulation initiated by plasma transferrin saturation levels would act within a few hours versus several days for hepatocyte iron excess(42-44). Whatever its cause, increased signalling pathway activation induces hepcidin mRNA expression, leading in turn to increased plasma hepcidin concentration which has a double consequence : on the one hand, a decreased duodenal iron absorption, on the other hand a decreased release from the spleen of the iron coming from the normal red blood cell degradation (erythrophagocytosis). The overall result is a decrease of plasma iron concentration aiming to counteract the initial plasma and/or cellular iron increase. A mirror situation occurs in case of decreased plasma and/or cellular iron.

For exerting its biological effect, hepcidin interacts with ferroportin which is mainly localised in the cell membrane of enterocytes and macrophages. This results in hepcidin internalization followed by lysosomal degradation of ferroportin $(45,46)$. Ferroportin, besides acting as an hepcidin receptor, is the only known cellular iron exporter, so that the final biological consequence is a decreased iron delivery into the plasma. Hepcidin also interferes with intestinal iron absorption by down-regulating the expression of DMT1, that is involved in non heme iron uptake at the apex of the enterocyte. (47).

It should be noted that, beside iron load, several factors are able to regulate hepcidin synthesis. One major mechanism is represented by inflammation which stimulates hepcidin production through the interleukin-6(IL-6)(48) (and IL-22(49))-STAT3 (signal transducer and activator of transcription) signalling pathway, and through activin B which likely implicates the BMP-SMAD pathway(50). The other key mechanism is dyserythropoiesis which decreases hepcidin synthesis via the action of the bone marrow hormone erythroferrone $(\operatorname{ERFE})(51,52)$. A further mechanism is hepatocellular failure since hepcidin is synthetized by the hepatocytes $(53,54)$.

\subsection{LOCAL INTRACELLULAR IRON REGULATION COMPLETES SYSTEMIC IRON REGULATION TO ENSURE BODY IRON HOMEOSTASIS (Fig.4)}

A local regulation exists as a complement of this hepcidin-driven systemic regulation. It involves the IRE (Iron Responsive Element)-IRP 1 and 2 (Iron Regulatory Protein) system(55, 56). In case of decreased cellular iron, an IRP1 conformational change and an IRP-2 level modulation occur which enhance physical interaction of IRPs with the IRE nucleotidic sequence located at the 5'non-coding region of L-ferritin mRNA. This, in turn, inhibits ferritin translation. Simultaneously, at the 3' extremity of transferrin receptor1 m-RNA, IRP hyperfixation on IREs inhibits transferrin degradation. These two combined mechanisms result in decreased iron storage capacity (decreased ferritin synthesis) and in increased iron entry capacity (increased transferrin receptor 1 expression), a « logical » process for counteracting the initial cellular iron decrease in cell. The reverse phenomenon occurs in case of increased cellular iron concentration. 


\subsection{MAJOR ADVANCES IN IRON METABOLISM UNDERSTANDING DO NOT MEAN COMPLETE KNOWLEDGE}

A number of issues remain to be solved. Among them : i) the mechanism whereby heme iron is taken up by the enterocyte, the precise role of the candidate protein HCP1 (heme carrier protein 1) remaining to be identified $(57,58)$; ii) the biochemical nature of NTBI(59) ;iii) the way iron circulates within the cytosol with the possible role of chaperone molecules such as PCB1 (Polyr@-Binding Protein $1(60-62)$; iv) the factors determining transferrin gene expression(63); v) the interactions between immunity and iron metabolism (64); vi) the mechanisms underlying the metabolic connections between iron and non-iron metals(35), vii) the mechanisms which drive cellular ferritin delivery into the plasma(65), viii) the precise mechanisms by which erythroferrone is acting, and ix) the mechanisms accounting for «brain protection» in most situations of systemic iron overload.

\section{IRON-RELATED GENETIC DISEASES}

The maintenance of iron homeostasis requiring multiple actors and regulators, iron metabolism can be impacted by mutations occurring in a large number of genes. Many of them have been identified and contribute to most iron-related genetic diseases resulting in iron overload or iron deficiency. However, the phenotypic expression variability despite similar mutations in the same gene, the discrepancies sometimes observed between phenotypic expression of a disease and the theoretical impact of the involved mutation in the considered gene, together with the existence of unexplained iron overload phenotypes, do suggest that yet unrecognized elements remain to be identified.

\subsection{GENETIC IRON OVERLOAD DISORDERS}

Iron excess can be found at systemic level or involve only specific cellular structures.

\subsubsection{DISEASES WITH TOTAL BODY IRON OVERLOAD}

\subsubsection{HAEMOCHROMATOSES}

Two main types of haemochromatoses (HC) should be considered(66, 67)(Fig.5).

\subsection{Hepcidin deficiency related-HC}

- Hepcidin deficiency is the common denominator and is responsible for organ iron excess through increased cellular iron entry. The involved iron species is NTBI which, as previously mentioned, occurs in the plasma following increased transferrin saturation, which is itself due to elevated serum iron concentration. This may correspond to quantitative hepcidin deficiency or to hepcidin resisitance. Quantitative hepcidin deficiency is by far the most frequent situation. In this setting, decreased hepatic synthesis is responsible for chronic hypo-hepcidinemia. The related diseases are : i) primarily, HFE-related HC. It is due, most often, to homozygote mutation in the HFE gene (located on chromosome 6) p.Cys282Tyr/pCys282Tyr (C282Y/C282Y) and corresponds to type 1 $\mathrm{HC}$; some rare HFE mutations in association with C282Y (compound heterozygosity) may give a similar phenotypic profile ; ii) much more rarely, non-HFE related HC are involved. They are related to mutations in genes also coding proteins involved in hepcidin expression induction such as hemojuvelin (HJV) or transferrin receptor2 (TFR2)-related HC (type $3 \mathrm{HC}$ ) (chromosome 7), or in hepcidin gene (HAMP) leading to decreased hepcidin production and/or activity. Mutations in hemojuvelin or hepcidin genes, which concern chromosomes 1 and 19 respectively, induce juvenile 
$\mathrm{HC}$ (types $2 \mathrm{~A}$ and $2 \mathrm{~B} \mathrm{HC}$ ). Hepcidin resistance corresponds to a refractory state of the cells to circulating hepcidin. This resistance state is related to ferroportin (SLC4OA1) (solute carrier family 40, member 1) mutations altering the "hepcidin-receptor " function of ferroportin(68-71). The corresponding disorder, which involves chromosome 2, is sometimes referred as ferroportin disease type $\mathrm{B}$ (type $4 \mathrm{~B} \mathrm{HC}$ ), but should rather be named « hepcidin resistance-related $\mathrm{HC}$ ».

All HC forms related to quantitative hepcidin deficiency correspond to endocrine disorders(72) involving the liver as source and/or target(73).

The phenotype of these various HC forms shares numerous features which can be grouped under the concept of " hepcidin-deficiency syndrome " : i) Increased serum iron concentration and TS; ii) iron deposition within the parenchymal cells (mostly hepatocytes, but also pancreatic, pituitary, and cardiac cells), contrasting with the lack of iron in the macrophages (Kupffer cells, splenic macrophages). This means, on liver biopsy performed at early stages, exclusive hepatocytic iron deposition with Perls staining, and, on MRI (magnetic resonance imaging), diffuse hepatic iron excess without splenic iron (aspect of « black liver and white spleen ")(74-77); iii) serum ferritin is well correlated to liver and body iron overload, and is therefore a valuable parameter for the indication of venesection therapy (>300 $\mu \mathrm{g} / \mathrm{L}$ in men and $>200 \mu \mathrm{g} / \mathrm{L}$ in women), for following its efficacy (on a monthly basis) and for reaching and maintaining the desaturation target $(50 \mu \mathrm{g} / \mathrm{L})(78)$; iv) chronic iron overload progressively damages the hepatocytes and is responsible for moderate cytolysis (serum transaminases less than 3 times the upper normal limit), hepatomegaly, and progressive fibrosis (especially in case of co-factors such as alcoholism or fatty liver), leading to cirrhosis with the risk of hepatocellular carcinoma. This risk persists despite total iron removal if the treatment was initiated while cirrhosis was already present; v) a further feature of this hepcidindeficiency syndrome is the strong efficiency of blood-letting therapy(79) due the effectiveness of phlebotomies for enhancing iron recycling which is needed to ensure post-venesection induced erythropoiesis.

- $\quad$ Family studies follow the rules of a recessive disease and is mainly based on C282Y testing (together with plasma transferrin saturation and ferritin) in the major siblings. However, the high mutation prevalence (of the order of $1 / 10$ in the Caucasian population) justifies to check also the major offspring(80).

Some important differential aspects exist between hepcidin-related HC forms : i) Type1 HC is only present in Caucasian populations; ii) type $1 \mathrm{HC}$ has a low penetrance(81) and a major issue is to identify the factors which modulate phenotypic expression, both in terms of iron excess and organ damage. Alcoholism is an acquired factor which may both accentuate liver fibrosis(82) and favor iron overload possibly through an hepcidin-decreasing effect. Overweight which attenuates disease expression in women possiby through increased hepcidin production(83). Genetic factors are increasingly identified, including the roles of digenism, specific mutations(84) or various polymorphisms(85). Nevertheless, much remains to be discovered to fully explain the basis of disease expression(86-88) ; iii) type $2 \mathrm{HC}$ (or juvenile HC) correspond to severe disorders with predominant heart, pituitary and liver damage and their treament may require, besides venesections, the use of chelation therapy.

In the future, apart from the hepcidin-resistance syndrome, these hepcidin-related HC will benefit from innovative therapeutic approaches, based on the underlying patho-physiology, and aiming to increase hepcidin by using mini or complete hepcidins, hepcidin agonists or by modulating actors of the BMP-SMAD pathway which could stimulate hepcidin synthesis. Another way could be to favor ferroportin internalization and/or degradation(72, 89). 


\subsection{The ferroportin disease(90-92)}

This term should be reserved for the usual form of genetic iron overload related to ferroportin mutations (SLC4OA1) and preferred to the designation "type $4 \mathrm{~A} \mathrm{HC}$ ». Those mutations, by altering the iron export property of the protein, cause iron overload by an intracellular retention mechanism. The ferroportin-related HC phenotypic profile is almost point by point opposed to that of hepcidinrelated $\mathrm{HC}$ : I) Serum iron and transferrin saturation are not elevated (and sometimes decreased); ii) iron deposition occurs essentially in the macrophages, due to the decrease of iron export activity related to ferroportin dysfunction in those cells, so that, on liver biopsy, iron predominates in the Kupffer cells, and, on MRI, iron overload prevails in the spleen as compared to the liver ( " black spleen and grey liver »); iii) serum ferritin, probably due its prevailing macrophagic origin in this setting, is usually much higher than in hepcidin-related HC and has not the same predictive value of total body iron load. This should lead to special attention in the use of this parameter both for diagnostic and therapeutic purposes; iv) there is limited damaging effect of this macrophagic iron, making this disease a relatively begnin one; iv) bloodletting may be moderately tolerated with the risk of anemia due to poor recycling capacity.

As to family studies, they should follow the rules applied to a disease with a dominant mode of transmission.

\subsubsection{THE HEREDITARY ACERULOPLASMINEMIA (HAC) CASE}

-This rare recessive iron overload disease is due to mutations within the ceruloplasmin $(C P)$ gene (chromosome 3)(93, 94). The disease phenotype of the disease is a mixed one. On the one hand, it shares a major feature of hepcidin-related HC that is hepatocytic iron deposition without macrophagic iron overload (MRI shows a picture of «black liver and white spleen " on the T2 sequence)(95-99); on the other hand, serum iron and transferrin saturation are extremely low with a frequent profile of iron-deficient anemia, suggesting intracellular iron retention, similar to anemia of chronic diseases. Moreover, iron deposition in the central nervous system, namely beyond the blood brain barrier, is very peculiar to the disease.

- The classical mechanistic explanation for the development of iron overload is not fully satisfactory. Indeed, it is frequently advocated that the impairment of the ceruloplasmin-related ferroxidase activity prevents ferrous iron from being oxidized in order to be taken up by plasma transferrin in plasma. This could favor a disturbance in the export activity of ferroportin causing intracellular iron retention and decreasing serum iron and TS (100), similarly to the ferroportin disease. However, this mechanism does not explain the dramatically low level of plasma iron and, more importantly, the parenchymal type of iron deposition with macrophage sparing. The development of brain iron overload is likely related to the expression, in the brain, of a GPI (glycosylphosphatidylinositolinositol) ceruloplasmin isoform, anchored in cell membrane and resulting from an alternative splicing of the $C P$ gene (in contrast with the secretory form expressed in the hepatocytes)(93). It is noteworthy that the mutations within the CP gene may lead : i) to decreased secretion of the mutated ceruloplasmin form through retention of the protein within the endoplasmic reticulum, thus leading to the classical form of HAC, with very low or undetectable serum ceruloplasmin ; or ii) to altered association of apoceruloplasmin to the copper atoms that are essential for the ferroxidase activity of holoceruloplasmin, thus leading to a biological picture where ferroxidase activity of the 
ceruloplasmin is strongly decreased whereas serum ceruloplasmin levels are less or not affected compared to the classical HAC form (Review in (94)).

- Considering that hepcidin deficiency has been reported both clinically $(101,102)$ and experimentally(103), it cannot be excluded that some degree of duodenal iron hyperabsorption occurs, especially if, like in the brain, hephaestin could partially compensate the lack of ceruloplasmin-related ferroxidase activity.

\subsubsection{OTHER DISEASES WITH SYSTEMIC IRON EXCESS}

\subsection{HEREDITARY ATRANSFERRINEMIA (HAT)}

Rare recessive disease due to transferrin (TF) mutations on chromosome 3, HAT affects young individuals(104). In the absence of transferrin, anemia develops due to lack of transferrin-iron delivery to the bone marrow, and iron overload occurs due to circulating NTBI.

2.1.1.3.2. DIVALENT METAL TRANSPORTER ONE (DMT1)-RELATED IRON DISORDER $(105,106)$

Given the dual role of this protein in dietary iron uptake at the apical membrane of the duodenal enterocyte and in iron egress from cytosolic endosomes, DMT1 (SLC11A2) (solute carrier family 11, member 2) mutations (located on chromosome 12) lead to a peculiar picture. Indeed, this rare recessive disease associates microcytic anemia, present from birth and resistant to oral supplementation, associated with visceral iron overload.

\subsubsection{DISEASE WITH RELATIVE IRON EXCESS}

\subsubsection{FRIEDREICH ATAXIA}

This recessive disease is due to mutations of the frataxin (FXN) gene (chromosome 9)(94). These mutations lead to mitochondrial iron accumulation without total body/organ iron overload. The clinical consequences are spinocerebellar degeneration and frequent cardiomyopathy.

\subsubsection{OTHER DISEASES}

They correspond to disturbances in heme synthesis, encompassing some forms of : i) congenital sideroblastic anemias ( by mutations of the following genes ALAS2(107), SLC25A38(108), ABCB7 (109), glutaredoxine 5 (110)), and ii) hereditary porphyrias(111).

\subsection{GENETIC IRON DEFICIENCY DISORDER : IRIDA}

IRIDA (iron refractory iron-deficiency anemia) is caused by mutations of TMPRSS6 (chromosome 22) which encodes matriptase-2, a transmembrane serine protease expressed on cell membranes of hepatocytes which is involved in the BMP/SMAD hepcidin regulatory pathway by processing hemojuvelin protein, a coreceptor of BMPs(112). TMPRSS6 mutations are responsible for chronic hyperhepcidinemia which leads to decrease plasma iron level, thus inducing severe iron deficiency anemia that is refractory to oral iron supplementation and only partially responsive to parenteral iron $(113,114)$. It should be noticed that TMPRSS6 polymorphisms have been associated to iron deficiency anemia partially responsive to oral treatment(115).

\subsection{GENETIC IRON METABOLISM-RELATED DISORDERS WITHOUT IRON EXCESS: GENETIC HYPERFERRITINEMIAS}

L-ferritin mutations (chromosome 19) are responsible for a dominant inherited disorder expressed by serum ferritin elevation (often $>1000 \mu \mathrm{g} / \mathrm{L}$ ), with normal transferrin saturation and without celllular iron excess. Depending on the mutation location on the L-ferritin m-RNA, clinical consequences are 
either expressed by early cataract(116-118) or totally absent(119). These syndromes are different from other situations involving L-ferritin mutations, called neuroferritinopathies(120). This exceptional dominant disease is an adult-onset neurodegenerative disorder related to iron overload in the basal ganglia which, clinically, is expressed by extrapyramidal neurological features with low serum ferritin values.

In conclusion, from the hepatologist viewpoint, the liver is a key organ in iron metabolism. It is the source of multiple proteins playing major roles in plasma iron transport (transferrin), in transmembrane iron passage (ceruloplasmin), and in systemic iron regulation (hepcidin). This means that the synthesis of all these proteins can be affected by hepatocellular failure. The liver is also a major iron storage organ and, when overwhelmed by chronic and massive iron burden, can be severely damaged, opening the way to extra-hepatic iron-related complications. Increased serum ferritin is the usual initial biochemical finding leading to evoke iron overload. A careful diagnostic strategy should drive the interpretation of hyperferritinemia (Fig.6), based on four types of key data : clinical data, transferrin saturation levels, MRI assessment of liver and spleen iron load, and targeted genetic searches with the help of reference centers.

However, despite tremendous advances in the iron pathophysiological domain, a number of molecular mechanisms remain to be elucidated, with the stimulating perspective of finding novel potential targets which could be valuable for the diagnostic and therapeutic management of patients affected by iron-related disorders. 


\section{KEY POINTS}

- The liver produces most proteins of systemic iron metabolism : transferrin (plasma iron transport), ceruloplasmin (plasma iron delivery), haptoglobin (linkage with haemoglobin), hemopexin (linkage with free heme), and hepcidin, the master regulator of iron homeostasis.

. The liver is a major iron storage organ, concerned mostly by parenchymal (hepatocytic) but also by macrophagic (Kupffer cell) iron deposition.

. Non-transferrin bound iron (NTBI) is avidly taken up by hepatocytes and is toxic through its reactive form (labile plasma iron-LPI).

- The liver accumulates iron and undergoes its toxicity mainly in hepcidin deficiencyrelated haemochromatosis (types1, 2, and 3 haemochromatoses).

. The liver is less impacted by iron overload in the usual form of the ferroportin disease (type 4 haemochromatosis).

.The mechanisms whereby hepatocytic iron deposition occurs in hereditary aceruloplasminemia are not fully elucidated.

- Hyperferritinemia is the usual diagnostic call sign for iron overload, and its interpretation requires a rigorous approach. 
FIGURE 1. Iron homeostasis. Plasma iron comes from duodenal absorption and from the spleen (iron recycling following erythrophagocytosis).

FIGURE 2. Main cell types involved in iron metabolism.

2A (upper left panel) Enterocyte. Fe : iron; DCytb : duodenal cytochrome ; DMT1 : divalent metal transporter 1 ; HCP1 : Heme carrier protein 1 ; TFR1 : transferrin receptor 1.

2B. (upper right panel) Hepatocyte. NTBI: non-transferrin bound iron; ZIP14 (SLC39A14 -solute carrier 39A14).

2C (lower left panel) Macrophage. Senescent erythrocyte (in red) ; Fe : iron ; HRG1 : heme-responsive gene protein 1 .

2D (lower right panel) Erythroblast. Fe-S : iron-sulfur clusters ; DMT1 : divalent metal transporter 1 ; STEAP3 : six-transmembrane epithelial antigen of the prostate.

FIGURE 3. Systemic iron regulation. Hepcidin decreases the iron entry into the plasma at the duodenal and splenic levels through its impact on ferroportin (the only known cellular iron exporter) (the green dotted arrow indicates that hepcidin also impacts duodenal iron uptake via DMT1). Increased (plasma or hepatocytic) iron load stimulates hepcidin production (TRF2: transferrin receptor 2 ; ERK/MAK : extracellular signal regulating kinase/mitogen activated protein kinase ; HJV (or HFE2) : hemojuvelin ; BMP6: bone morphogenetic protein 6 (induced by intracellular iron) ; BMP$\mathrm{R}$ : BMPreceptor ; SMAD : son of mothers against decapentaplegic homologs). Inflammation is also a positive hepcidin regulator (IL-6: interleukin6; STAT3: signal transducer and activator of transcription 3). Hypoxia and/or anemia decrease hepcidin production through erythroferrone, produced by the erythroblasts in response to EPO (erythropoietin) synthesis by the kidney. TMPRSS6 (transmembrane serine protease S6) is also a negative hepcidin regulator (HIF : hypoxia inducible factor ; JAK2 : Janus kinase 2).

FIGURE 4. Local (cellular) iron regulation. Decreased cellular iron content activates IRE (iron responsive element) fixation on IRP (iron regulatory protein), leading to decreased ferritin synthesis and to increased TFR1 (transferrin receptor1) expression. Inverse situation in case of increased cellulariron content.

FIGURE 5. Mechanisms of iron overload in haemochromatosis. A) ( Left panel) Hepcidin deficiencyand hepcidin resistance-related haemochromatosis : increased plasma iron generates NTBI (nontransferrin bound iron) which is quickly taken up by the parenchymal cells (here: one hepatocyte) ; B) (Right panel) Ferroportin disease : impairment of the iron exporter ferroportin at the macrophagic level causes cellular iron retention (here: one macrophage) together with low plasma iron levels. MRI : magnetic resonance imaging ( no iron $\square$ rload; moder $\square$ ron overload ; $\quad$ hea) iron overload). 
FIGURE 6. Overall diagnostic strategy for hyperferritinemia. TS : transferrin saturation ; MRI : magnetic resonance imaging ; $\mathrm{HC}$ : haemochromatosis ; HAC : hereditary aceruloplasminemia. 


\section{REFERENCES}

1. Meynard D, Babitt JL, Lin HY. The liver: conductor of systemic iron balance. Blood 2014;123:168-176.

2. Andrews NC, Schmidt PJ. Iron homeostasis. Annu Rev Physiol 2007;69:69-85.

3. Lane DJ, Merlot AM, Huang ML, Bae DH, Jansson PJ, Sahni S, et al. Cellular iron uptake, trafficking and metabolism: Key molecules and mechanisms and their roles in disease. Biochim Biophys Acta 2015;1853:1130-1144.

4. Brissot $P$, Cavey $T$, Troadec MB, Ropert $M$, Loréal O. Métabolisme du fer. EMCEndocrinologie-Métabolisme 2015;0:1-11.

5. Chiabrando D, Vinchi F, Fiorito V, Mercurio S, Tolosano E. Heme in pathophysiology: a matter of scavenging, metabolism and trafficking across cell membranes. Front Pharmacol 2014;5:61.

6. Lawen A, Lane DJ. Mammalian iron homeostasis in health and disease: uptake, storage, transport, and molecular mechanisms of action. Antioxid Redox Signal 2013;18:2473-2507.

7. Davidsson L. Approaches to improve iron bioavailability from complementary foods. J Nutr 2003;133:1560S-1562S.

8. Halfdanarson TR, Litzow MR, Murray JA. Hematologic manifestations of celiac disease. Blood 2007;109:412-421.

9. Hershko C, Graham G, Bates GW, Rachmilewitz EA. Non-specific serum iron in thalassaemia: an abnormal serum iron fraction of potential toxicity. Br J Haematol 1978;40:255-263.

10. Brissot $P$, Wright TL, Ma WL, Weisiger RA. Efficient clearance of non-transferrin-bound iron by rat liver. Implications for hepatic iron loading in iron overload states. J Clin Invest 1985;76:14631470.

11. Craven CM, Alexander J, Eldridge M, Kushner JP, Bernstein S, Kaplan J. Tissue distribution and clearance kinetics of non-transferrin-bound iron in the hypotransferrinemic mouse: a rodent model for hemochromatosis. Proc Natl Acad Sci U S A 1987;84:3457-3461.

12. Liuzzi JP, Aydemir F, Nam H, Knutson MD, Cousins RJ. Zip14 (Slc39a14) mediates nontransferrin-bound iron uptake into cells. Proc Natl Acad Sci U S A 2006;103:13612-13617.

13. Jenkitkasemwong S, Wang CY, Coffey R, Zhang W, Chan A, Biel T, et al. SLC39A14 Is Required for the Development of Hepatocellular Iron Overload in Murine Models of Hereditary Hemochromatosis. Cell Metab 2015;22:138-150.

14. Hider RC. Nature of nontransferrin-bound iron. Eur J Clin Invest 2002;32 Suppl 1:50-54.

15. Brissot $\mathrm{P}$, Ropert $\mathrm{M}$, Le Lan $\mathrm{C}$, Loreal $\mathrm{O}$. Non-transferrin bound iron: a key role in iron overload and iron toxicity. Biochimica et biophysica acta 2012;1820:403-410.

16. Esposito BP, Breuer W, Sirankapracha P, Pootrakul P, Hershko C, Cabantchik ZI. Labile plasma iron in iron overload: redox activity and susceptibility to chelation. Blood 2003;102:2670-2677.

17. Cabantchik ZI, Breuer W, Zanninelli G, Cianciulli P. LPI-labile plasma iron in iron overload. Best practice \& research. Clinical haematology 2005;18:277-287.

18. Le Lan C, Loreal O, Cohen T, Ropert M, Glickstein H, Laine F, et al. Redox active plasma iron in C282Y/C282Y hemochromatosis. Blood 2005;105:4527-4531.

19. Cabantchik Zl. Labile iron in cells and body fluids: physiology, pathology, and pharmacology. Front Pharmacol 2014;5:45.

20. McKie AT, Barrow D, Latunde-Dada GO, Rolfs A, Sager G, Mudaly E, et al. An iron-regulated ferric reductase associated with the absorption of dietary iron. Science 2001;291:1755-1759.

21. Ohgami RS, Campagna DR, McDonald A, Fleming MD. The Steap proteins are metalloreductases. Blood 2006;108:1388-1394.

22. Mukhopadhyay CK, Attieh ZK, Fox PL. Role of ceruloplasmin in cellular iron uptake. Science 1998;279:714-717.

23. Vulpe CD, Kuo YM, Murphy TL, Cowley L, Askwith C, Libina N, et al. Hephaestin, a ceruloplasmin homologue implicated in intestinal iron transport, is defective in the sla mouse. Nat Genet 1999;21:195-199. 
24. Arosio P, Ingrassia R, Cavadini P. Ferritins: a family of molecules for iron storage, antioxidation and more. Biochim Biophys Acta 2009;1790:589-599.

25. Lane DJ, Richardson DR. The active role of vitamin C in mammalian iron metabolism: much more than just enhanced iron absorption! Free Radic Biol Med 2014;75:69-83.

26. Jomova K, Valko M. Advances in metal-induced oxidative stress and human disease. Toxicology 2011;283:65-87.

27. Brissot $P$, Deugnier $Y$, Guyader D, Zanninelli G, Loreal O, Moirand R, et al. Iron overload and the biliary route. Adv Exp Med Biol 1994;356:277-283.

28. Brissot $P$, Bardou-Jacquet $E$, Jouanolle $A M$, Loreal O. Iron disorders of genetic origin: a changing world. Trends in molecular medicine 2011;17:707-713.

29. Tolosano E. Increasing serum transferrin to reduce tissue iron overload due to ineffective erythropoiesis. Haematologica 2015;100:565-566.

30. Fishbane S, Mathew A, Vaziri ND. Iron toxicity: relevance for dialysis patients. Nephrol Dial Transplant 2014;29:255-259.

31. Porter JB, Garbowski M. The pathophysiology of transfusional iron overload. Hematol Oncol Clin North Am 2014;28:683-701, vi.

32. Crichton RR. Iron metabolism: From molecular mechanisms to clinical consequences. Wiley edits 2009.

33. Pigeon C, Ilyin G, Courselaud B, Leroyer P, Turlin B, Brissot P, et al. A new mouse liver-specific gene, encoding a protein homologous to human antimicrobial peptide hepcidin, is overexpressed during iron overload. J Biol Chem 2001;276:7811-7819.

34. Nicolas G, Bennoun M, Devaux I, Beaumont C, Grandchamp B, Kahn A, et al. Lack of hepcidin gene expression and severe tissue iron overload in upstream stimulatory factor 2 (USF2) knockout mice. Proceedings of the National Academy of Sciences of the United States of America 2001;98:8780-8785.

35. Loreal O, Cavey T, Bardou-Jacquet E, Guggenbuhl P, Ropert M, Brissot P. Iron, hepcidin, and the metal connection. Front Pharmacol 2014;5:128.

36. Ganz T. Systemic iron homeostasis. Physiol Rev 2013;93:1721-1741.

37. Zhao N, Zhang AS, Enns CA. Iron regulation by hepcidin. The Journal of clinical investigation 2013;123:2337-2343.

38. Verga Falzacappa MV, Casanovas G, Hentze MW, Muckenthaler MU. A bone morphogenetic protein (BMP)-responsive element in the hepcidin promoter controls HFE2-mediated hepatic hepcidin expression and its response to IL-6 in cultured cells. J Mol Med (Berl) 2008;86:531-540.

39. Ramey G, Deschemin JC, Vaulont S. Cross-talk between the mitogen activated protein kinase and bone morphogenetic protein/hemojuvelin pathways is required for the induction of hepcidin by holotransferrin in primary mouse hepatocytes. Haematologica 2009;94:765-772.

40. Hentze MW, Muckenthaler MU, Galy B, Camaschella C. Two to tango: regulation of Mammalian iron metabolism. Cell 2010;142:24-38.

41. Wu XG, Wang Y, Wu Q, Cheng WH, Liu W, Zhao Y, et al. HFE interacts with the BMP type I receptor ALK3 to regulate hepcidin expression. Blood 2014;124:1335-1343.

42. Corradini E, Meynard D, Wu Q, Chen S, Ventura P, Pietrangelo A, et al. Serum and liver iron differently regulate the bone morphogenetic protein 6 (BMP6)-SMAD signaling pathway in mice. Hepatology 2011;54:273-284.

43. Ramos E, Kautz L, Rodriguez R, Hansen M, Gabayan V, Ginzburg Y, et al. Evidence for distinct pathways of hepcidin regulation by acute and chronic iron loading in mice. Hepatology 2011;53:1333-1341.

44. Zhang AS, Anderson SA, Wang J, Yang F, DeMaster K, Ahmed R, et al. Suppression of hepatic hepcidin expression in response to acute iron deprivation is associated with an increase of matriptase-2 protein. Blood 2011;117:1687-1699.

45. McKie AT, Marciani P, Rolfs A, Brennan K, Wehr K, Barrow D, et al. A novel duodenal ironregulated transporter, IREG1, implicated in the basolateral transfer of iron to the circulation. Mol Cell 2000;5:299-309. 
46. De Domenico I, Ward DM, Nemeth E, Vaughn MB, Musci G, Ganz T, et al. The molecular basis of ferroportin-linked hemochromatosis. Proceedings of the National Academy of Sciences of the United States of America 2005;102:8955-8960.

47. Brasse-Lagnel C, Karim Z, Letteron P, Bekri S, Bado A, Beaumont C. Intestinal DMT1 cotransporter is down-regulated by hepcidin via proteasome internalization and degradation. Gastroenterology 2011;140:1261-1271 e1261.

48. Nemeth E, Rivera S, Gabayan V, Keller C, Taudorf S, Pedersen BK, et al. IL-6 mediates hypoferremia of inflammation by inducing the synthesis of the iron regulatory hormone hepcidin. J Clin Invest 2004;113:1271-1276.

49. Armitage AE, Eddowes LA, Gileadi U, Cole S, Spottiswoode N, Selvakumar TA, et al. Hepcidin regulation by innate immune and infectious stimuli. Blood 2011;118:4129-4139.

50. Besson-Fournier C, Latour C, Kautz L, Bertrand J, Ganz T, Roth MP, et al. Induction of activin B by inflammatory stimuli up-regulates expression of the iron-regulatory peptide hepcidin through Smad1/5/8 signaling. Blood 2012;120:431-439.

51. Kautz L, Jung G, Valore EV, Rivella S, Nemeth E, Ganz T. Identification of erythroferrone as an erythroid regulator of iron metabolism. Nat Genet 2014;46:678-684.

52. Kautz L, Nemeth E. Molecular liaisons between erythropoiesis and iron metabolism. Blood 2014;124:479-482.

53. Detivaud L, Nemeth E, Boudjema K, Turlin B, Troadec MB, Leroyer P, et al. Hepcidin levels in humans are correlated with hepatic iron stores, hemoglobin levels, and hepatic function. Blood 2005;106:746-748.

54. Maras JS, Maiwall R, Harsha HC, Das S, Hussain MS, Kumar C, et al. Dysregulated iron homeostasis is strongly associated with multiorgan failure and early mortality in acute-on-chronic liver failure. Hepatology 2015;61:1306-1320.

55. Zhang DL, Ghosh MC, Rouault TA. The physiological functions of iron regulatory proteins in iron homeostasis - an update. Front Pharmacol 2014;5:124.

56. Wilkinson N, Pantopoulos K. The IRP/IRE system in vivo: insights from mouse models. Front Pharmacol 2014;5:176.

57. Shayeghi M, Latunde-Dada GO, Oakhill JS, Laftah AH, Takeuchi K, Halliday N, et al. Identification of an intestinal heme transporter. Cell 2005;122:789-801.

58. Qiu A, Jansen M, Sakaris A, Min SH, Chattopadhyay S, Tsai E, et al. Identification of an intestinal folate transporter and the molecular basis for hereditary folate malabsorption. Cell 2006;127:917-928.

59. Evans RW, Rafique R, Zarea A, Rapisarda C, Cammack R, Evans PJ, et al. Nature of nontransferrin-bound iron: studies on iron citrate complexes and thalassemic sera. Journal of biological inorganic chemistry : JBIC : a publication of the Society of Biological Inorganic Chemistry 2008;13:5774.

60. Richardson DR, Lane DJ, Becker EM, Huang ML, Whitnall M, Suryo Rahmanto Y, et al. Mitochondrial iron trafficking and the integration of iron metabolism between the mitochondrion and cytosol. Proc Natl Acad Sci U S A 2010;107:10775-10782.

61. Shi H, Bencze KZ, Stemmler TL, Philpott CC. A cytosolic iron chaperone that delivers iron to ferritin. Science 2008;320:1207-1210.

62. Leidgens S, Bullough KZ, Shi H, Li F, Shakoury-Elizeh M, Yabe T, et al. Each member of the poly-r(C)-binding protein 1 (PCBP) family exhibits iron chaperone activity toward ferritin. J Biol Chem 2013;288:17791-17802.

63. Gkouvatsos K, Papanikolaou G, Pantopoulos K. Regulation of iron transport and the role of transferrin. Biochim Biophys Acta 2012;1820:188-202.

64. Porto G, De Sousa M. Iron overload and immunity. World J Gastroenterol 2007;13:47074715.

65. Cohen LA, Gutierrez L, Weiss A, Leichtmann-Bardoogo Y, Zhang DL, Crooks DR, et al. Serum ferritin is derived primarily from macrophages through a nonclassical secretory pathway. Blood 2010;116:1574-1584. 
66. Brissot $P$, Bardou-Jacquet $E$, Jouanolle $A M$, Loreal O. Iron disorders of genetic origin: $a$ changing world. Trends Mol Med 2011;17:707-713.

67. Bardou-Jacquet E, Ben Ali Z, Beaumont-Epinette MP, Loreal O, Jouanolle AM, Brissot P. NonHFE hemochromatosis: Pathophysiological and diagnostic aspects. Clin Res Hepatol Gastroenterol 2013.

68. Drakesmith H, Schimanski LM, Ormerod E, Merryweather-Clarke AT, Viprakasit V, Edwards JP, et al. Resistance to hepcidin is conferred by hemochromatosis-associated mutations of ferroportin. Blood 2005;106:1092-1097.

69. Sham RL, Phatak PD, West C, Lee P, Andrews C, Beutler E. Autosomal dominant hereditary hemochromatosis associated with a novel ferroportin mutation and unique clinical features. Blood cells, molecules \& diseases 2005;34:157-161.

70. Sham RL, Phatak PD, Nemeth E, Ganz T. Hereditary hemochromatosis due to resistance to hepcidin: high hepcidin concentrations in a family with C326S ferroportin mutation. Blood 2009;114:493-494.

71. Fernandes A, Preza GC, Phung Y, De Domenico I, Kaplan J, Ganz T, et al. The molecular basis of hepcidin-resistant hereditary hemochromatosis. Blood 2009;114:437-443.

72. Pietrangelo A. Genetics, Genetic Testing and Management of Hemochromatosis: 15 years since hepcidin. Gastroenterology 2015.

73. Bardou-Jacquet E, Philip J, Lorho R, Ropert M, Latournerie M, Houssel-Debry P, et al. Liver transplantation normalizes serum hepcidin level and cures iron metabolism alterations in HFE hemochromatosis. Hepatology 2013.

74. Gandon Y, Olivie D, Guyader D, Aube C, Oberti F, Sebille V, et al. Non-invasive assessment of hepatic iron stores by MRI. Lancet 2004;363:357-362.

75. St Pierre TG, Clark PR, Chua-anusorn W, Fleming AJ, Jeffrey GP, Olynyk JK, et al. Noninvasive measurement and imaging of liver iron concentrations using proton magnetic resonance. Blood 2005;105:855-861.

76. Wood JC. Impact of iron assessment by MRI. Hematology / the Education Program of the American Society of Hematology. American Society of Hematology. Education Program 2011;2011:443-450.

77. Deugnier Y, Turlin B. Pathology of hepatic iron overload. Seminars in liver disease 2011;31:260-271.

78. HAS. French recommendations for management of HFE hemochromatosis. Haute Autorité de Santé 2005; www.has-sante.fr.

79. Brissot P, Ball S, Rofail D, Cannon H, Jin VW. Hereditary hemochromatosis: patient experiences of the disease and phlebotomy treatment. Transfusion 2011;51:1331-1338.

80. Porto G, Brissot P, Swinkels DW, Zoller H, Kamarainen O, Patton S, et al. EMQN best practice guidelines for the molecular genetic diagnosis of hereditary hemochromatosis $(\mathrm{HH})$. Eur J Hum Genet 2015.

81. Allen KJ, Gurrin LC, Constantine CC, Osborne NJ, Delatycki MB, Nicoll AJ, et al. Iron-overloadrelated disease in HFE hereditary hemochromatosis. N Engl J Med 2008;358:221-230.

82. Fletcher LM, Powell LW. Hemochromatosis and alcoholic liver disease. Alcohol 2003;30:131136.

83. Desgrippes R, Laine F, Morcet J, Perrin M, Manet G, Jezequel C, et al. Decreased iron burden in overweight $\mathrm{C} 282 \mathrm{Y}$ homozygous women: Putative role of increased hepcidin production. Hepatology 2013;57:1784-1792.

84. Island ML, Jouanolle AM, Mosser A, Deugnier $Y$, David $V$, Brissot $P$, et al. A new mutation in the hepcidin promoter impairs its BMP response and contributes to a severe phenotype in HFE related hemochromatosis. Haematologica 2009;94:720-724.

85. Valenti L, Fracanzani AL, Rametta R, Fraquelli M, Soverini G, Pelusi S, et al. Effect of the A736V TMPRSS6 polymorphism on the penetrance and clinical expression of hereditary hemochromatosis. Journal of hepatology 2012;57:1319-1325. 
86. McLaren CE, Emond MJ, Subramaniam VN, Phatak PD, Barton JC, Adams PC, et al. Exome sequencing in HFE C282Y homozygous men with extreme phenotypes identifies a GNPAT variant associated with severe iron overload. Hepatology 2015;62:429-439.

87. de Tayrac M, Roth MP, Jouanolle AM, Coppin H, le Gac G, Piperno A, et al. Genome-wide association study identifies TF as a significant modifier gene of iron metabolism in HFE hemochromatosis. J Hepatol 2015;62:664-672.

88. Milet J, Dehais V, Bourgain C, Jouanolle AM, Mosser A, Perrin M, et al. Common variants in the BMP2, BMP4, and HJV genes of the hepcidin regulation pathway modulate HFE hemochromatosis penetrance. Am J Hum Genet 2007;81:799-807.

89. Fung E, Nemeth E. Manipulation of the hepcidin pathway for therapeutic purposes. Haematologica 2013;98:1667-1676.

90. Njajou OT, Vaessen N, Joosse M, Berghuis B, van Dongen JW, Breuning MH, et al. A mutation in SLC11A3 is associated with autosomal dominant hemochromatosis. Nature genetics 2001;28:213214.

91. Montosi G, Donovan A, Totaro A, Garuti C, Pignatti E, Cassanelli S, et al. Autosomal-dominant hemochromatosis is associated with a mutation in the ferroportin (SLC11A3) gene. J Clin Invest 2001;108:619-623.

92. Pietrangelo A. The ferroportin disease. Blood cells, molecules \& diseases 2004;32:131-138.

93. Miyajima H. Aceruloplasminemia. Neuropathology 2015;35:83-90.

94. Kono S. Aceruloplasminemia: an update. Int Rev Neurobiol 2013;110:125-151.

95. Finkenstedt A, Wolf E, Hofner E, Gasser BI, Bosch S, Bakry R, et al. Hepatic but not brain iron is rapidly chelated by deferasirox in aceruloplasminemia due to a novel gene mutation. Journal of hepatology 2010;53:1101-1107.

96. Hattori A, Tomosugi N, Tatsumi Y, Suzuki A, Hayashi K, Katano Y, et al. Identification of a novel mutation in the HAMP gene that causes non-detectable hepcidin molecules in a Japanese male patient with juvenile hemochromatosis. Blood Cells Mol Dis 2012;48:179-182.

97. Tai M, Matsuhashi N, Ichii O, Suzuki T, Ejiri Y, Kono S, et al. Case of presymptomatic aceruloplasminemia treated with deferasirox. Hepatol Res 2014;44:1253-1258.

98. Rusticeanu M, Zimmer V, Schleithoff L, Wonney K, Viera J, Zimmer A, et al. Novel ceruloplasmin mutation causing aceruloplasminemia with hepatic iron overload and diabetes without neurological symptoms. Clin Genet 2014;85:300-301.

99. Loreal O, Turlin B, Pigeon C, Moisan A, Ropert M, Morice P, et al. Aceruloplasminemia: new clinical, pathophysiological and therapeutic insights. J Hepatol 2002;36:851-856.

100. De Domenico I, Ward DM, di Patti MC, Jeong SY, David S, Musci G, et al. Ferroxidase activity is required for the stability of cell surface ferroportin in cells expressing GPI-ceruloplasmin. EMBO J 2007;26:2823-2831.

101. Kaneko Y, Miyajima H, Piperno A, Tomosugi N, Hayashi H, Morotomi N, et al. Measurement of serum hepcidin-25 levels as a potential test for diagnosing hemochromatosis and related disorders. J Gastroenterol 2010;45:1163-1171.

102. Kono S, Yoshida K, Tomosugi N, Terada T, Hamaya Y, Kanaoka S, et al. Biological effects of mutant ceruloplasmin on hepcidin-mediated internalization of ferroportin. Biochim Biophys Acta 2010;1802:968-975.

103. Guo P, Cui R, Chang YZ, Wu WS, Qian ZM, Yoshida K, et al. Hepcidin, an antimicrobial peptide is downregulated in ceruloplasmin-deficient mice. Peptides 2009;30:262-266.

104. Aslan D, Crain K, Beutler E. A new case of human atransferrinemia with a previously undescribed mutation in the transferrin gene. Acta Haematol 2007;118:244-247.

105. Iolascon A, Camaschella C, Pospisilova D, Piscopo C, Tchernia G, Beaumont C. Natural history of recessive inheritance of DMT1 mutations. J Pediatr 2008;152:136-139.

106. Bardou-Jacquet E, Island ML, Jouanolle AM, Detivaud L, Fatih N, Ropert M, et al. A novel N491S mutation in the human SLC11A2 gene impairs protein trafficking and in association with the G212V mutation leads to microcytic anemia and liver iron overload. Blood Cells Mol Dis 2011;47:243248. 
107. Ducamp S, Kannengiesser C, Touati M, Garcon L, Guerci-Bresler A, Guichard JF, et al. Sideroblastic anemia: molecular analysis of the ALAS2 gene in a series of 29 probands and functional studies of 10 missense mutations. Hum Mutat 2011;32:590-597.

108. Guernsey DL, Jiang H, Campagna DR, Evans SC, Ferguson M, Kellogg MD, et al. Mutations in mitochondrial carrier family gene SLC25A38 cause nonsyndromic autosomal recessive congenital sideroblastic anemia. Nat Genet 2009;41:651-653.

109. Bekri S, Kispal G, Lange H, Fitzsimons E, Tolmie J, Lill R, et al. Human ABC7 transporter: gene structure and mutation causing X-linked sideroblastic anemia with ataxia with disruption of cytosolic iron-sulfur protein maturation. Blood 2000;96:3256-3264.

110. Camaschella C, Campanella A, De Falco L, Boschetto L, Merlini R, Silvestri L, et al. The human counterpart of zebrafish shiraz shows sideroblastic-like microcytic anemia and iron overload. Blood 2007;110:1353-1358.

111. Besur S, Hou W, Schmeltzer P, Bonkovsky HL. Clinically important features of porphyrin and heme metabolism and the porphyrias. Metabolites 2014;4:977-1006.

112. Finberg KE, Heeney MM, Campagna DR, Aydinok Y, Pearson HA, Hartman KR, et al. Mutations in TMPRSS6 cause iron-refractory iron deficiency anemia (IRIDA). Nature genetics 2008;40:569-571.

113. Heeney MM, Finberg KE. Iron-refractory iron deficiency anemia (IRIDA). Hematol Oncol Clin North Am 2014;28:637-652, v.

114. De Falco L, Silvestri L, Kannengiesser C, Moran E, Oudin C, Rausa M, et al. Functional and clinical impact of novel TMPRSS6 variants in iron-refractory iron-deficiency anemia patients and genotype-phenotype studies. Hum Mutat 2014;35:1321-1329.

115. Poggiali E, Andreozzi F, Nava I, Consonni D, Graziadei G, Cappellini MD. The role of TMPRSS6 polymorphisms in iron deficiency anemia partially responsive to oral iron treatment. Am J Hematol 2015;90:306-309.

116. Girelli D, Corrocher R, Bisceglia L, Olivieri O, De Franceschi L, Zelante L, et al. Molecular basis for the recently described hereditary hyperferritinemia-cataract syndrome: a mutation in the ironresponsive element of ferritin L-subunit gene (the "Verona mutation"). Blood 1995;86:4050-4053.

117. Yin D, Kulhalli V, Walker AP. Raised serum ferritin concentration in hereditary hyperferritinemia cataract syndrome is not a marker for iron overload. Hepatology 2014;59:12041206.

118. Bowes O, Baxter K, Elsey T, Snead M, Cox T. Hereditary hyperferritinaemia cataract syndrome. Lancet 2014;383:1520.

119. Kannengiesser C, Jouanolle AM, Hetet G, Mosser A, Muzeau F, Henry D, et al. A new missense mutation in the $L$ ferritin coding sequence associated with elevated levels of glycosylated ferritin in serum and absence of iron overload. Haematologica 2009;94:335-339.

120. Martelli A, Puccio H. Dysregulation of cellular iron metabolism in Friedreich ataxia: from primary iron-sulfur cluster deficit to mitochondrial iron accumulation. Front Pharmacol 2014;5:130. 


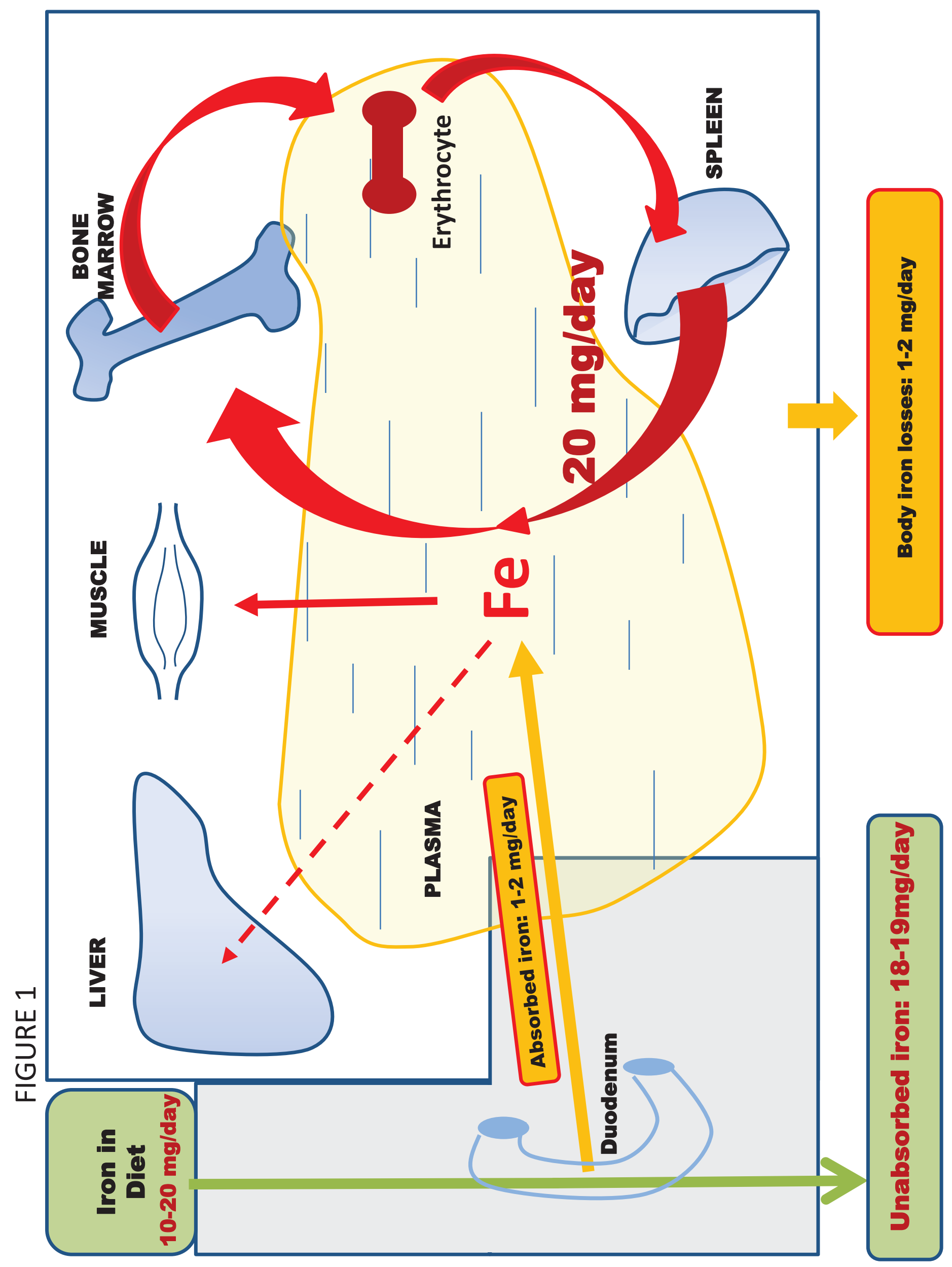




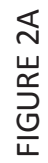

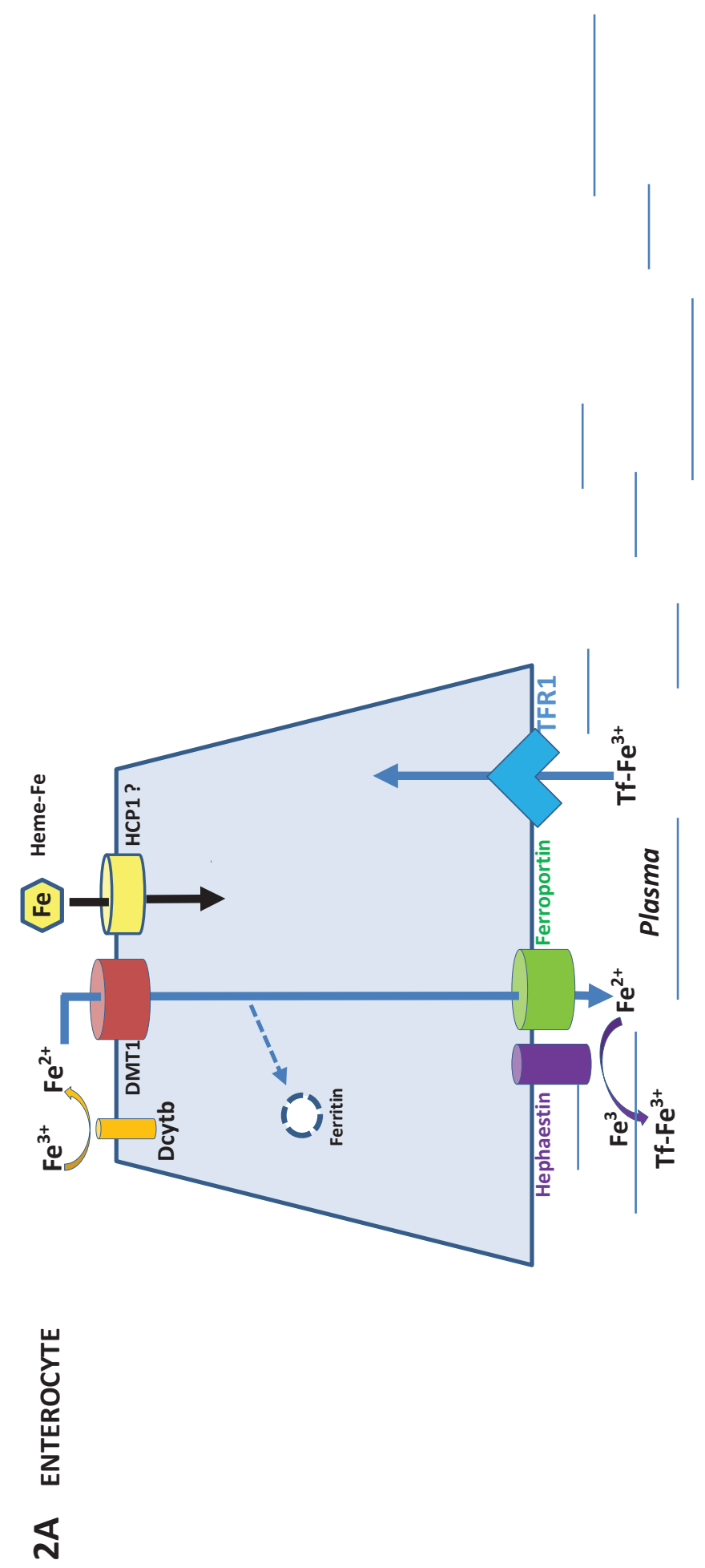




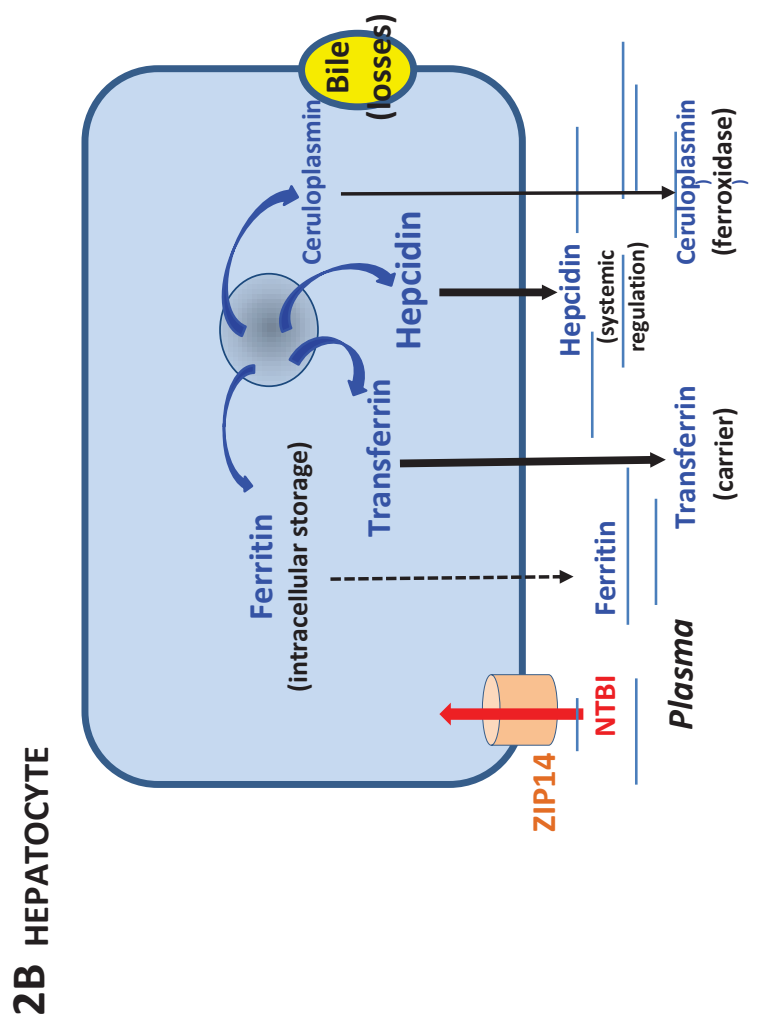


$\cup$
U
$\stackrel{ }{\supset}$
$\stackrel{ত}{\square}$

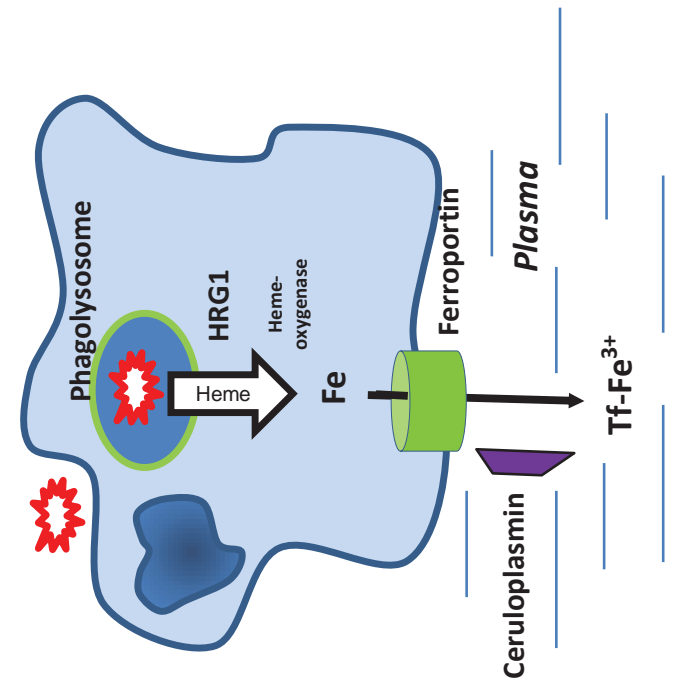

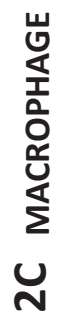




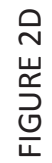
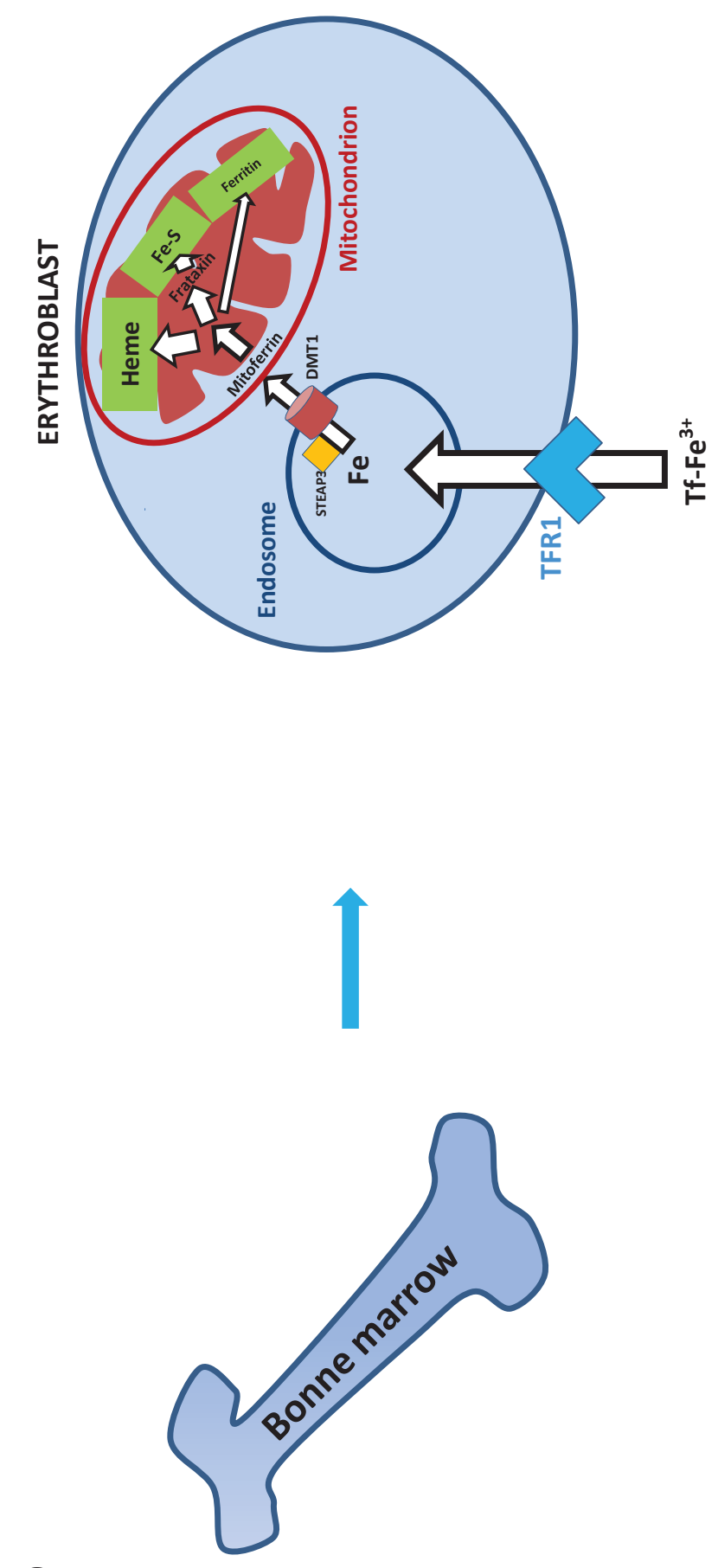

สิ 


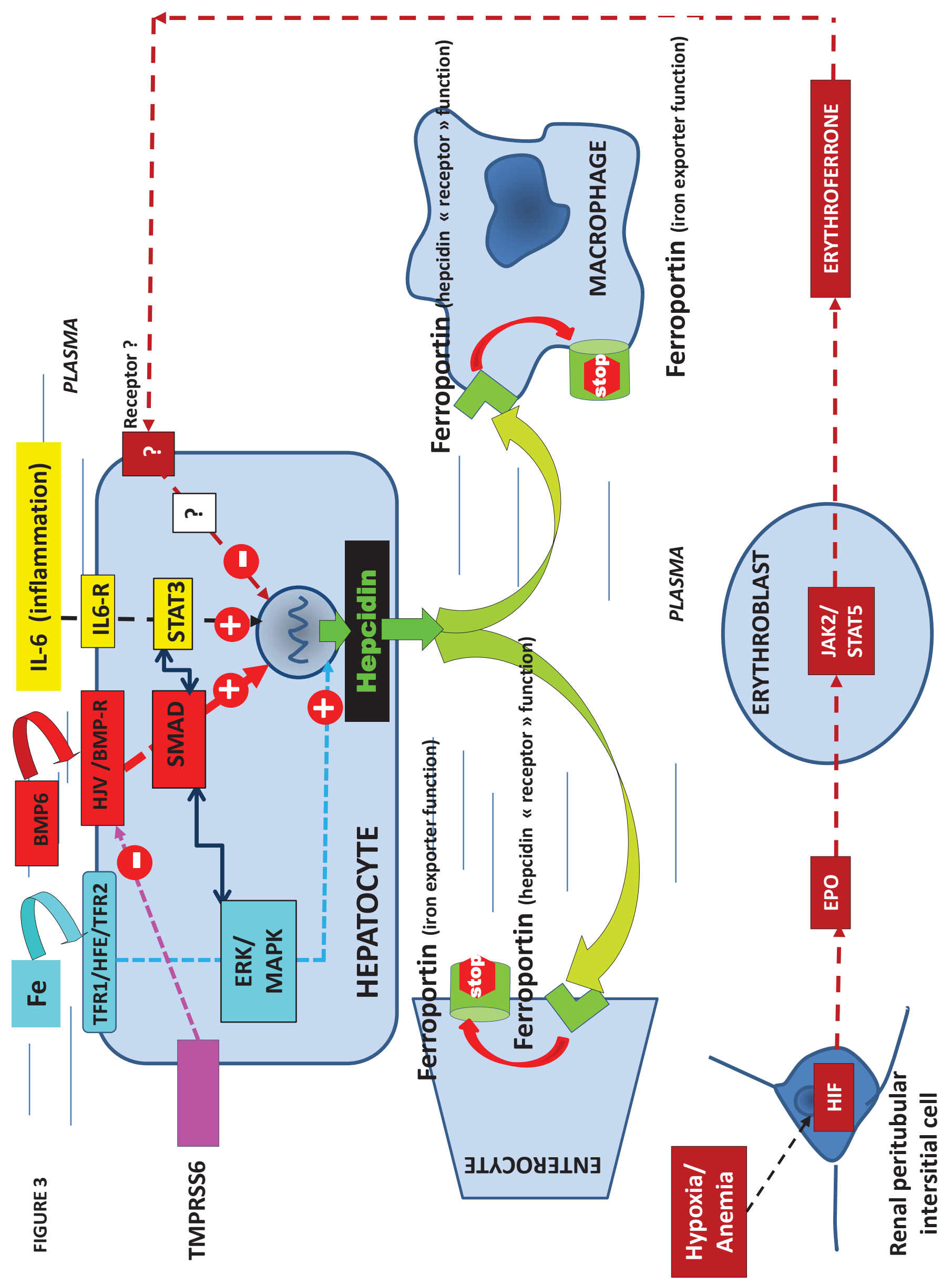




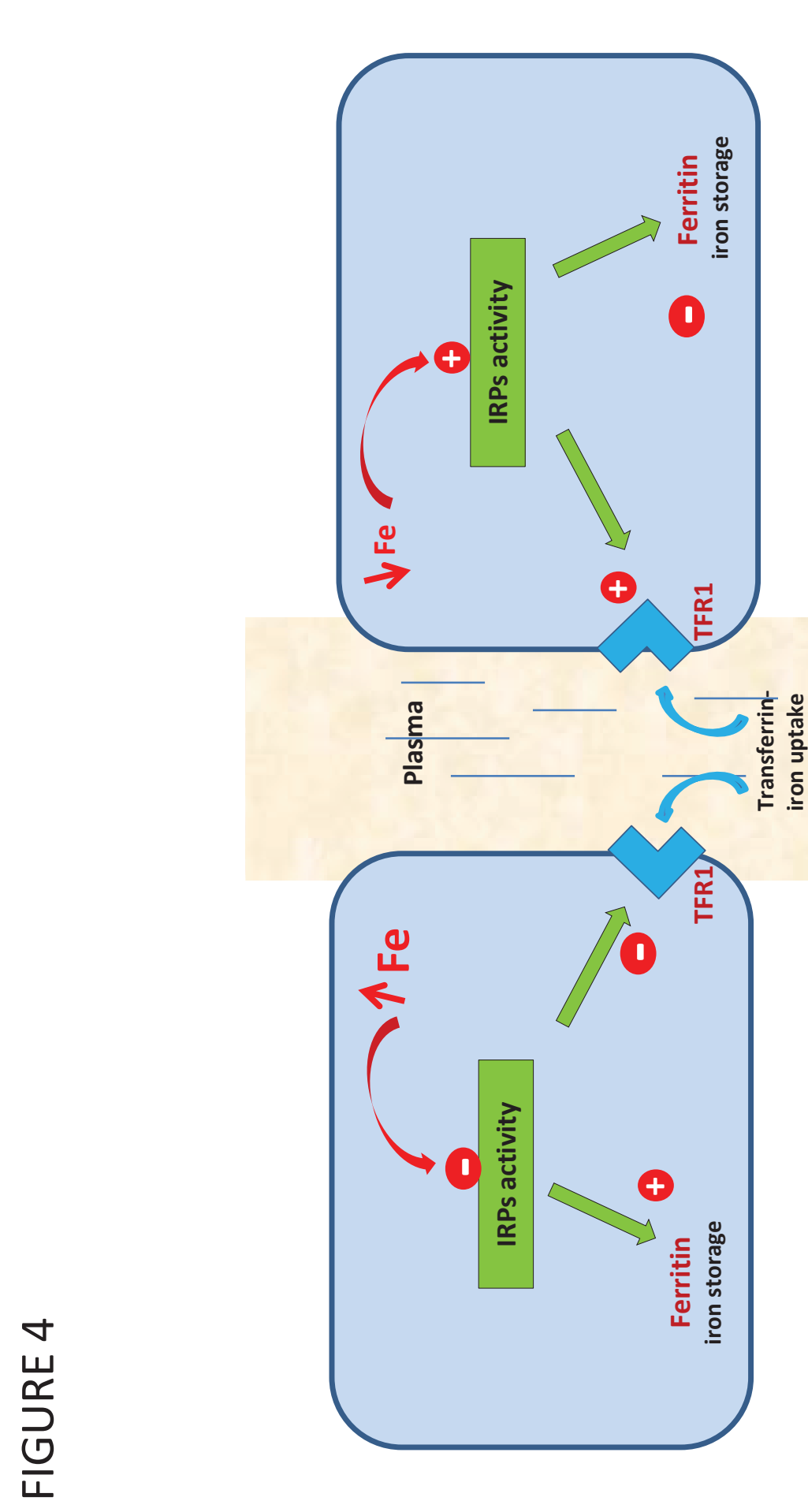

$\infty$ 

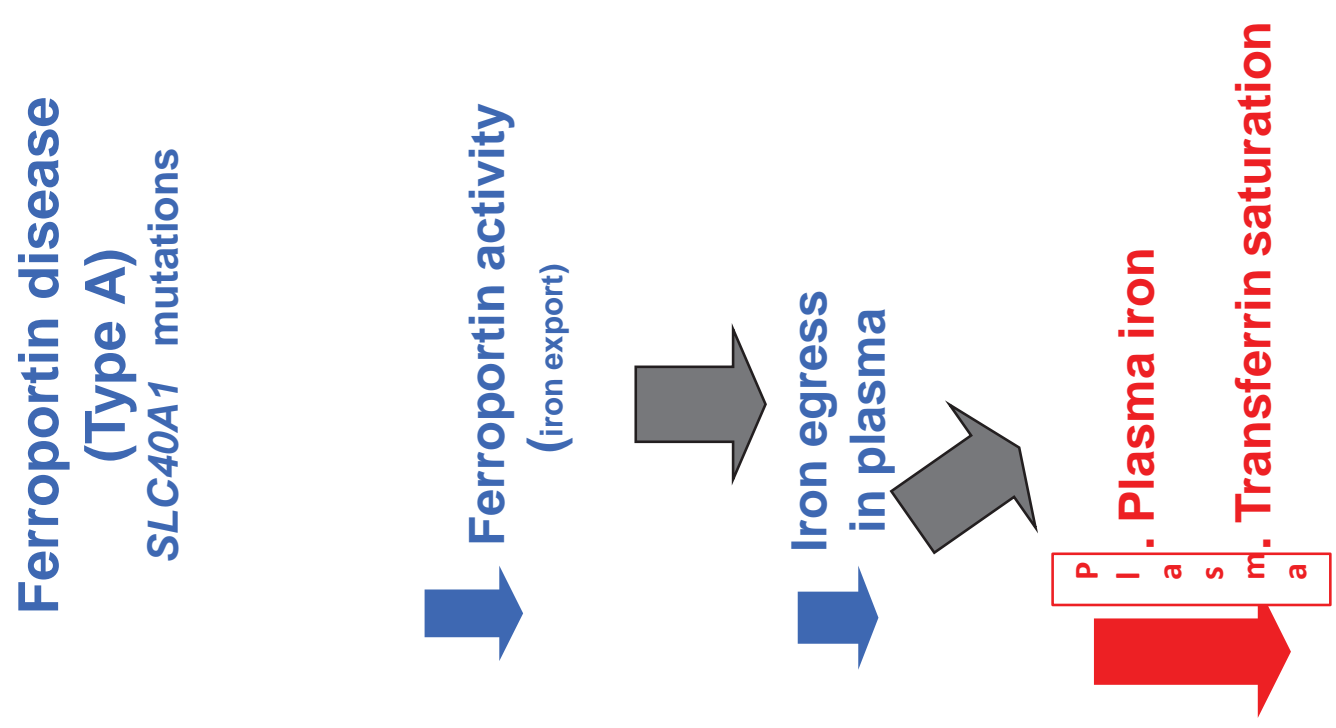

$m$
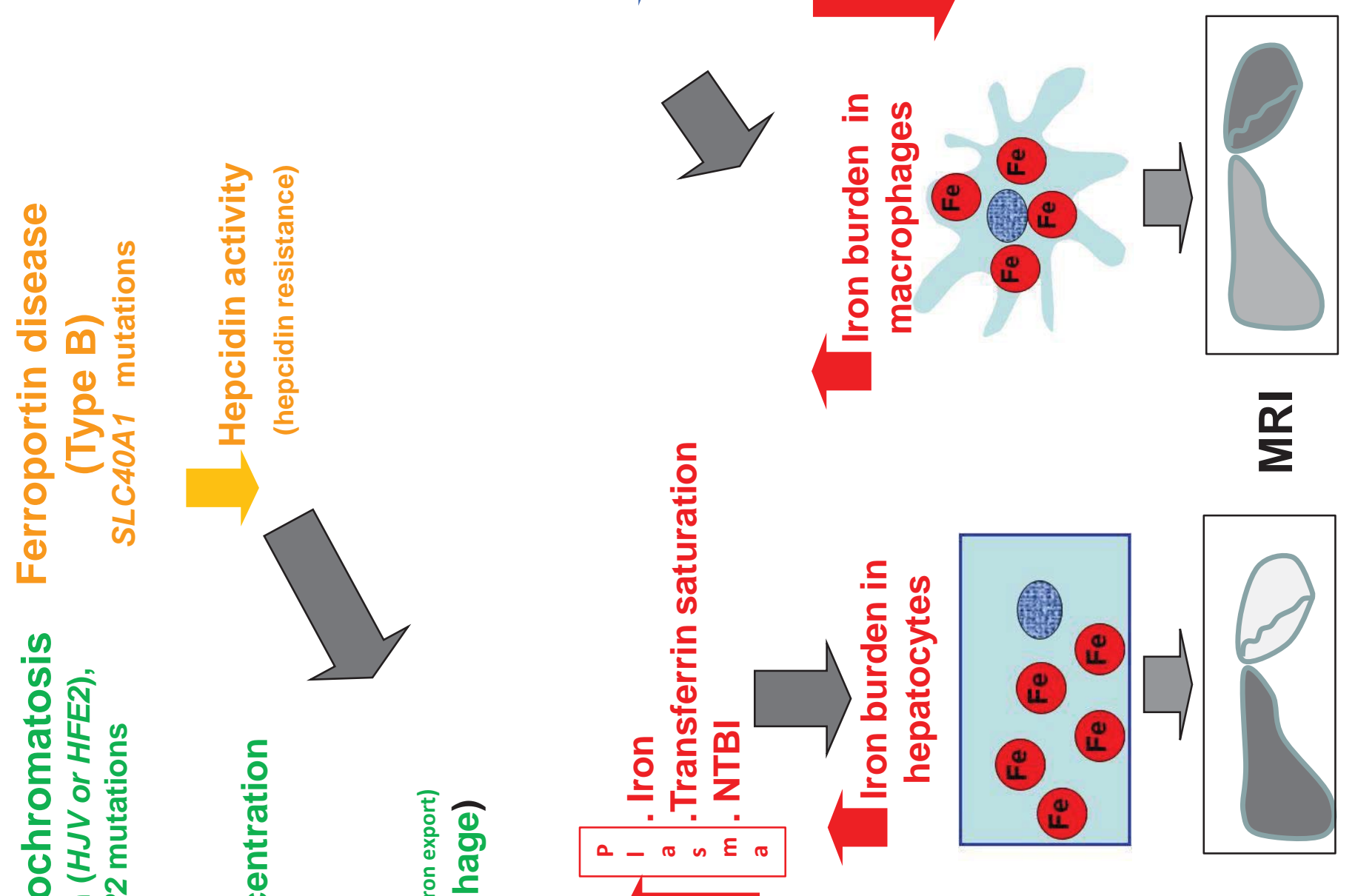

ค

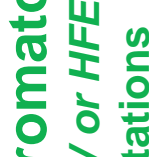

는

을

들 든

등

츨 을

는 혼

(1)

ᄂ 든 인

늠응 은 음

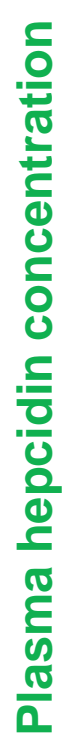

ํํㄹ

을 중

$\geqslant \frac{0}{2}$

है है

든 엄포

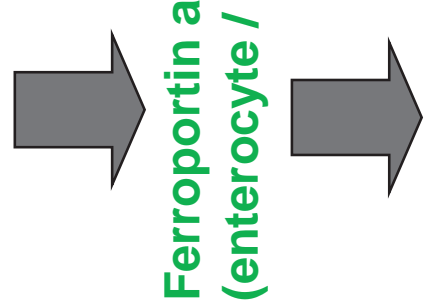

भ ฮ

든 든 


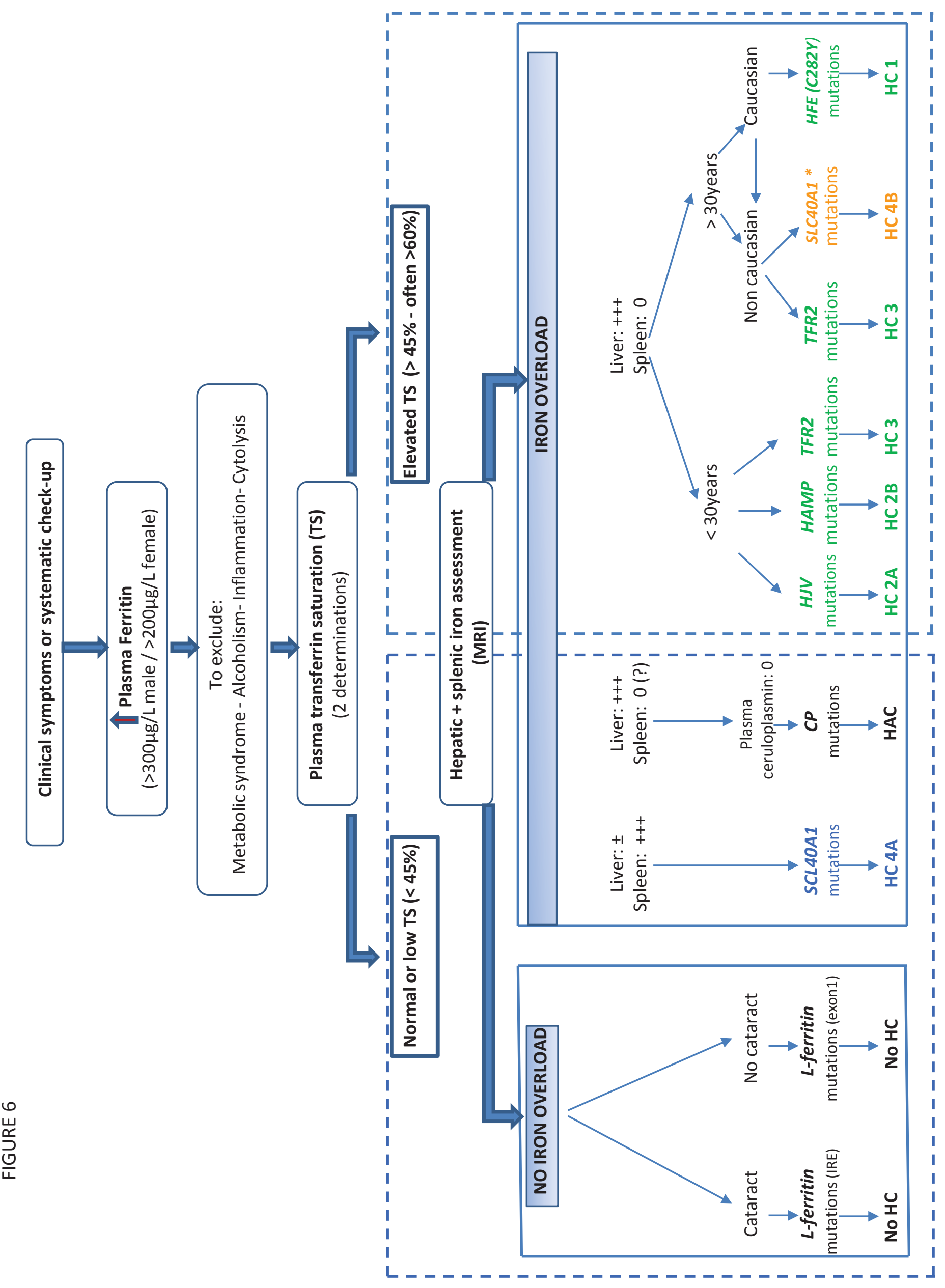

